\title{
Case Report: Reinfection of COVID-19, with second infection
}

\section{less severe [version 1; peer review: 1 approved]}

\author{
Nawar Jasim Alsalih (D1), Zeayd Fadhil Saeed (D)2, Hazim Talib Thwiny (D)3, \\ Ali Mosa Rashid Al-Yasari (iD4, Ahmed Waleed Dheyab Alnassar5, \\ James P. Hobkirk (D6, Mohenned A. Alsaadawi (iD) \\ ${ }^{1}$ Division of Microbiology, College of Veterinary Medicine, Al-Muthanna University, Alsamawah, 66110, Iraq \\ ${ }^{2}$ Nursing Department, Technical Institute of Samawah, Al Furat Al Awsat Technical University, Alsamawah, 66110, Iraq \\ ${ }^{3}$ College of Veterinary Medicine, University of Basrah, Basrah, Iraq \\ ${ }^{4}$ Division of Physiology, College of Veterinary Medicine, Al-Muthanna University, Alsamawah, 66110, Iraq \\ ${ }^{5}$ Al-Muthanna Health Directorate, Ministry of Health, Alsamawah, 66110, Iraq \\ ${ }^{6}$ Department of Sport, Health and Exercise Sciences, Faculty of Health Sciences, University of Hull, Hull, UK \\ ${ }^{7}$ Department of Parasitology, College of Veterinary Medicine, Al-Muthanna University, Alsamawah, 66110, Iraq
}

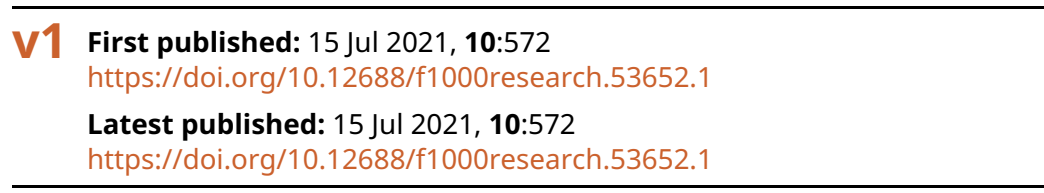

\section{Abstract}

There is concern that an individual may contract COVID-19 twice, either as a result of being a viral carrier that was not entirely cleared from the body in the first instance or as a result of reinfection. The recurrent infection may be qRT-PCR positive, which must be distinguished from post-COVID-19 symptoms that are qRT-PCR negative. Although it is known that recovered patients of viral diseases can be immune for the next infection, recurrent infections of COVID-19 have been recorded in Brazilian healthcare workers. We report a case of recurrent COVID-19 infection in a 34-year-old man working in the Gynecology and Children Hospital in Al-Muthanna Province, south of Iraq. The patient suffered from a sharp and noticeable rise in the body temperature at $39{ }^{\circ} \mathrm{C}$ and cough on the 16 th of July 2020 . Then, the patient was symptomized with another course of COVID-19 on the $27^{\text {th }}$ of August 2020, which was contracted from the patient's workmate. Nose swab PCR test and CT scan were performed to confirm the second infection. The clinical signs of repeated infection with coronavirus were obviously less than the first infection of the same patient. It is clear that the first infection symptoms of COVID-19 are more severe than the signs of recurrent disease.

\section{Keywords}

COVID-19, reinfection, PCR, CT scan, Real-time PCR

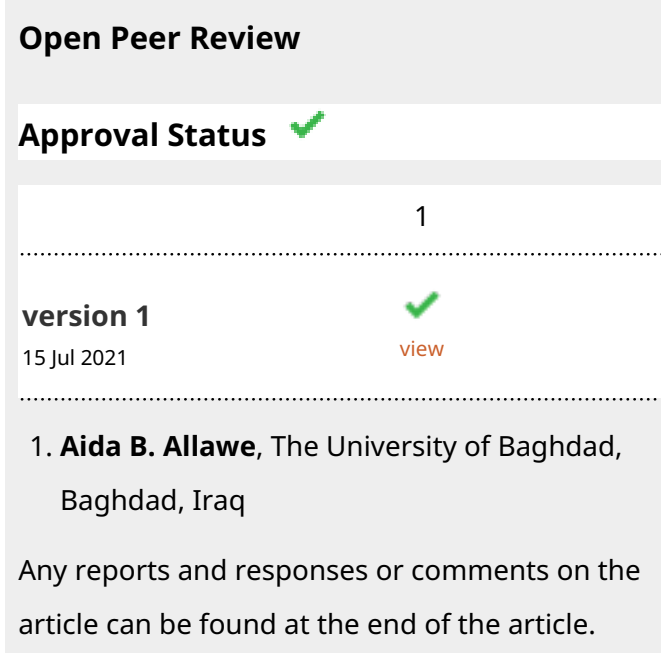




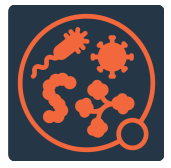

This article is included in the Pathogens

gateway.

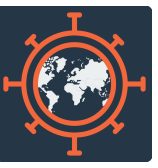

This article is included in the Emerging Diseases

and Outbreaks gateway.

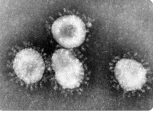

This article is included in the Coronavirus

collection.

Corresponding author: Mohenned A. Alsaadawi (mohenned.hemza@mu.edu.iq)

Author roles: Alsalih NJ: Methodology, Writing - Original Draft Preparation; Saeed ZF: Supervision, Writing - Review \& Editing; Thwiny HT: Supervision, Visualization, Writing - Review \& Editing; Al-Yasari AMR: Data Curation, Formal Analysis, Methodology; Alnassar AWD: Data Curation, Resources; Hobkirk JP: Writing - Review \& Editing; Alsaadawi MA: Data Curation, Formal Analysis, Supervision

Competing interests: No competing interests were disclosed.

Grant information: The author(s) declared that no grants were involved in supporting this work.

Copyright: (c) 2021 Alsalih NJ et al. This is an open access article distributed under the terms of the Creative Commons Attribution License, which permits unrestricted use, distribution, and reproduction in any medium, provided the original work is properly cited.

How to cite this article: Alsalih NJ, Saeed ZF, Thwiny HT et al. Case Report: Reinfection of COVID-19, with second infection less severe [version 1; peer review: 1 approved] F1000Research 2021, 10:572 https://doi.org/10.12688/f1000research.53652.1

First published: 15 Jul 2021, 10:572 https://doi.org/10.12688/f1000research.53652.1 


\section{Introduction}

The severe acute respiratory syndrome coronavirus 2 (SARS-CoV-2) was the cause of the global COVID-19 pandemic, which began in Wuhan, China, in December 2019 and has since spread throughout the world. ${ }^{1}$ The virus may infect a wide range of systems, including the respiratory, gastrointestinal, hepatic, and central neurological systems, with severe symptoms that may need hospitalization. ${ }^{2}$ According to recent studies, around 4-5 days is the typical incubation time from SARS-CoV-2 exposure to the beginning of symptoms, with $97.5 \%$ of symptomatic individuals showing symptoms within 11.5 days. $^{3}$ Although most cases are asymptomatic or moderate, advanced age, cardiovascular disorders, chronic lung illness, systemic arterial hypertension, diabetes, obesity, and Black and minority ethnicity are the main risky factors of the pandemic. ${ }^{4}$ At a time when millions of first-wave infections have occurred and many communities are suffering from a second wave, there is worry over whether the sickness may continue, whether by the recurrence of a viral reservoir that was not completely removed from the body in the first place or by reinfection. ${ }^{2}$ The common symptom of recurrent CVID-19 syndrome occurs again after the first appearance of the initial pandemic infection and can be qRT-PCR positive, which needs to be differentiated from the post-COVID-19 symptoms, typically negative on qRT-PCR. ${ }^{4}$ Recurrent infection is far from the more serious "chronic post-viral syndrome", or long-term symptoms that persist despite no viral activity. While certain viral sequences can be identified by sequencing, and thus whether a patient has a new infection can be determined, there are other circumstances in which a patient is known to have an infection, but we do not have information on their exact viral sequence. To account for these situations, the phrase 'recurrence' instead of 'persistence' should be used. ${ }^{5-8}$ The importance of considering recurrent infection relates to the immune interactions and the ability of the immune system to stop subsequent viral infections. It is known that during the viral infections, immunity can be developed after the first infection and provides a strong defense against subsequent SARS-Cov-2 exposure.

In this case report, we present a patient with recurrence of COVID-19 symptoms, qRT-PCR positive, whom was diagnosed as having COVID-19 recurrence.

\section{Case description}

A 34-year-old man working in the Gynecology and Children Hospital in Al-Muthanna Province, south Iraq, suffered from a sharp and noticeable rise in body temperature of $39^{\circ} \mathrm{C}$ and cough on $16^{\text {th }}$ of July 2020 . The patient also suffered from congestion in the tonsils and pharynx, difficulty swallowing, severe fatigue, emaciation, joint pain, persistent sweating, pain along the spinal cord, in addition to choking and pain in the chest area, and difficulty breathing. On $19^{\text {th }}$ July, the patient visited a doctor who ran various laboratory tests and a complete blood count (Tables 1 and 2). Due to suspicion of COVID-19, the patient was on mandatory vacation for a month. One week later, the patient lost his sense of smell for two days. These symptoms continued for eight days, after which the patient recovered from his symptoms and returned to normal.

Nasopharyngeal swabs, which had been collected on $23^{\text {rd }}$ of July 2020 to detect the nucleic acid of SARS-CoV2, were tested by reverse transcriptase-polymerase chain reaction in real time, with positive results to IgM of COVID-19. On $26^{\text {th }}$ July 2020, complete blood count was returned as normal. The patient was given a COVID-19 diagnosis.

The patient underwent the recommended treatment involved using bronchium syrup (three times per day), TAVANIC tablets 500MG, co-codamol tablets 500MG (three times per a day), Heparin (two times per a day) at dose of $18 \mathrm{units} / \mathrm{kg} / \mathrm{hr}$ IV for five days, and desloratadine tablets $10 \mathrm{mg}$ (one time per a day.

Table 1. Patient's laboratory results on $19^{\text {th }}$ July.

\begin{tabular}{|l|l|l|}
\hline Laboratory parameter & Result & Normal range \\
\hline Rapid test of COVID-19 & Positive IgG & NA \\
\hline C-reactive protein & $15.2 \mathrm{mg} / \mathrm{L}$ & $<10 \mathrm{mg} / \mathrm{L}$ \\
\hline D-dimer & $0.29 \mathrm{ng} / \mathrm{ml}$ & $0-500 \mathrm{ng} / \mathrm{ml}$ \\
\hline Lactate dehydrogenase & $210 \mathrm{U} / \mathrm{L}$ & $140-280 \mathrm{U} / \mathrm{L}$ \\
\hline Serum ferritin & $537.2 \mathrm{ng} / \mathrm{ml}$ & $\begin{array}{l}\text { Men } 30-400 \mathrm{ng} / \mathrm{ml} \\
\text { Women } 13-130 \mathrm{ng} / \mathrm{ml}\end{array}$ \\
\hline Vitamin D3 & & $<10 \mathrm{ng} / \mathrm{ml}$ Deficiency \\
& $76 \mathrm{ng} / \mathrm{ml}$ & $10-30 \mathrm{ng} / \mathrm{ml}$ Insufficiency \\
& & $30-100 \mathrm{ng} / \mathrm{ml}$ Sufficiency \\
\hline
\end{tabular}


Table 2. First complete blood count analysis of the patient on 19th July 2020.

\begin{tabular}{|l|l|l|l|}
\hline Parameter & Result & Normal range & Status \\
\hline White blood cell & $6.0 \times 10 * 9 / \mathrm{L}$ & $4.0-10.0$ & Normal \\
\hline Lymphocyte \% & $17.0 \%$ & $20.0-40.0$ & Low \\
\hline MID\% & $9.0 \%$ & $1.0-15.0$ & Normal \\
\hline Neutrophil \% & $74.0 \%$ & $50.0-70.0$ & High \\
\hline Lymphocyte number & $1.0 \times 10 * 9 / \mathrm{L}$ & $0.6-4.1$ & Normal \\
\hline MID number & $0.5 \times 10 * 9 / \mathrm{L}$ & $0.1-1.8$ & Normal \\
\hline Neutrophil number & $4.5 \times 10 * 9 / \mathrm{L}$ & $2.0-7.8$ & Normal \\
\hline Red blood cell & $4.4 \times 10 * 12 / \mathrm{L}$ & $3.50-5.50$ & Normal \\
\hline Hemoglobin & $12.9 \mathrm{~g} / \mathrm{dL}$ & $11.0-16.0$ & Normal \\
\hline Hematocrit & $37.3 \%$ & $36.0-48.0$ & Normal \\
\hline Mean corpuscular volume & $84.8 \mathrm{fL}$ & $80.0-99.0$ & Normal \\
\hline Mean corpuscular hemoglobin & $29.3 \mathrm{pg}$ & $26.0-32.0$ & Normal \\
\hline Mean corpuscular hemoglobin concentration & $34.5 \mathrm{~g} / \mathrm{dL}$ & $32.0-36.0$ & Normal \\
\hline Red blood cell distribution width-SD & $50.2 \mathrm{fL}$ & $37.0-54.0$ & Normal \\
\hline Red blood cell distribution width-CV & $12.8 \%$ & $11.5-14.5$ & Normal \\
\hline Platelet & $198 \times 10 * 9 / \mathrm{L}$ & $100-450$ & Normal \\
\hline Mean platelet volume & $11.6 \mathrm{fL}$ & $7.4-10.4$ & High \\
\hline Platelet distribution width & $17.7 \%$ & $10.0-17.0$ & High \\
\hline Procalcitonin & $0.22 \%$ & $0.10-0.28$ & Normal \\
\hline Platelet large cell ratio & $43.3 \%$ & $13.0-43.0$ & High \\
\hline
\end{tabular}

The PCR test of COVID-19 was done again on $19^{\text {th }}$ of August 2020, which showed a negative result. Other tests performed on the same date included C-reactive protein (CRP), D-dimer and serum ferritin were $0.42 \mathrm{mg} / \mathrm{L}, 181 \mathrm{ng} / \mathrm{ml}$ and $97.5 \mathrm{ng} / \mathrm{ml}$, respectively. These tests showed that the patient was completely recovered.

The patient resumed his work on $19^{\text {th }}$ of August 2020 in the microbiology laboratory of the hospital. Five days later $\left(23^{\text {rd }}\right.$ August), the patient's workmate tested positive to COVID-19 after PCR test and CT scan. Our patient was suspected to be COVID-19 positive on COVID-19 on $27^{\text {th }}$ of August 2020, due to the following symptoms: intermittent fever, pain in tonsil and pharynx, and intermittent diarrhea. Nasopharyngeal swab was taken again on the same day and was confirmed as COVID-19 positive by PCR. A CT scan was performed to confirm the second infection and this showed bilateral consolidation and linear opacities (Figure 1), indicative of COVID-19 infection.

After five days of second appearance of symptoms in the patient, the patient's cough was continuous and dry without sputum with suffocation $\left(\mathrm{SpO}_{2}\right.$ dropped to $\left.85 \%\right)$, which continued for two days. The patient started to use medicinal oxygen to compensate the lost oxygen. Treatment provided to the patient was as follows: Heparin (twice per a day) at dose of 18 units $/ \mathrm{kg} / \mathrm{hr}$ IV for five days; Livofloxacin $500 \mathrm{mg}$ once daily; Panadol tablets $500 \mathrm{mg}$ thrice daily; Desloratadine $10 \mathrm{ml}$ (5 mg) oral solution once a day; Dexamethasone $4 \mathrm{mg}$ used only in case of severe hypoxia (the patient used it twice); and multivitamins (C, D, and zinc) once daily. After two days, the patient reported feeling more normal. A week later, the patient's symptoms had disappeared except coughing and pharyngitis.

A complete blood count taken on $3^{\text {rd }}$ September showed that there was a smaller number of lymphocytes than normal and higher than normal number of neutrophils (Table 3). CRP was positive ( $42 \mathrm{mg} / \mathrm{dl}$ ) while D-dimer and serum ferritin were normal $(181 \mathrm{ng} / \mathrm{ml}$ and $97.5 \mathrm{ng} / \mathrm{ml}$, respectively). The status of the patient became more stable and he gradually started to recover. However, the patient still reports feeling tired and not having the ability to do normal activities compared to his abilities before the recurrent infection.

\section{Discussion}

Our patient suffered from a rapid increase in body temperature, which reached a peak of $39^{\circ} \mathrm{C}$ with congestions of the tonsils and pharynx, difficulty swallowing, and coughing and discomfort in the chest. Following these symptoms, the 


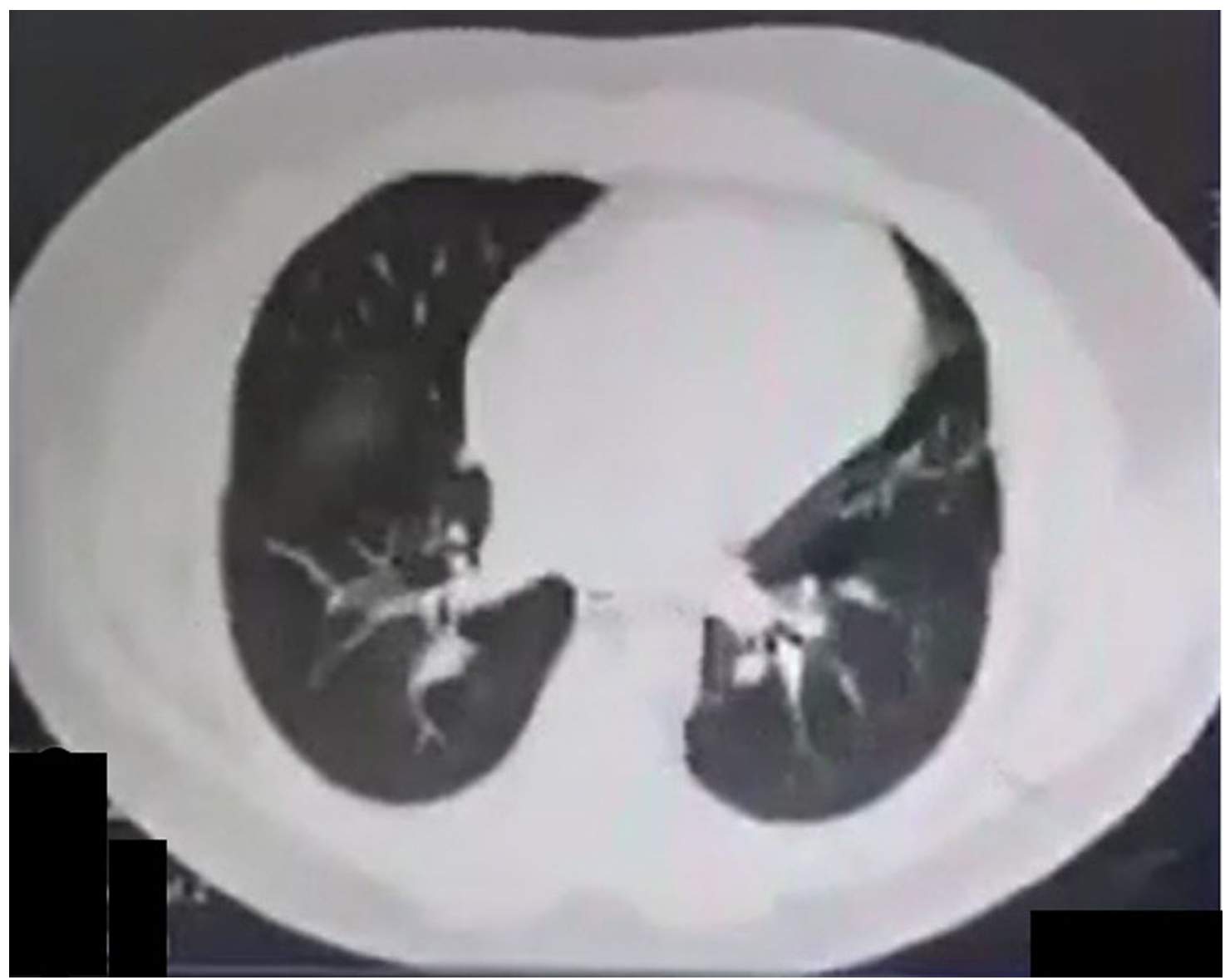

Figure 1. CT scan image of patient's lung exposed to repeated infection of COVID-19 showing significant consolidation and linear opacities.

patient's sense of smell was lost. Rapid test showed that the patient was IgG positive to COVID-19. Blood work showed that the patient had a small elevation in D-Dimer. In COVID-19 patients, higher values of D-Dimer could occur as a sequalae of SARS-CoV-2 or a secondary complication of a systemic inflammatory response syndrome which can be considered as an indicator for incidence of acute pulmonary embolism. ${ }^{10} \mathrm{CRP}$ was also elevated, which is expected to increase due to pulmonary injuries during SARS-CoV-2 infection. Increased of CRP might indicate the seriousness of the disease. ${ }^{11}$ In addition, serum ferritin was moderately increased. Ferritin can be considered as a biomarker for COVID-19 prognosis. ${ }^{12}$ It is recommended to use these three parameters during hospitalization to track the prognosis of COVID-19 patients. $^{13}$

The role of acquired immunity and SARS-CoV-2 antibodies in patient protection against further COVID-19 infection is still under debate. ${ }^{14,15}$ It was reported that acquired immunity could help in preventing further infection. ${ }^{16-19}$ However, Bentivegna et al. ${ }^{11}$ presented a case of a recovered positive serological pneumonia COVID-19 patient, accompanied by six negative PCR tests. A month later, and after exposure to the virus, another positive PCR test and seroconversion of $\operatorname{IgM}$ were performed.

The coronavirus infection might cause a thrombosis that can induce severe symptoms that could lead to death. Complete blood testing in our patient showed a significant elevation in the mean platelet volume, which could increase the probability of thrombosis. ${ }^{21,22}$

A previous COVID-19 positive patient was shown to have a high level of peptide precursor of calcitonin hormone [procalcitonin (PCT)]. ${ }^{23,24}$ In our case, both blood tests of the patient showed an increase in serum levels of PCT, which could indicate serious infection with pathological bacteria associated with bronchiolitis. ${ }^{25}$ Another increased marker in both of our patient's blood tests was lymphopenia, which declined in the first and second COVID-19 infection. The low level of lymphocytes in the blood stream is usually associated with COVID-19 patients, resulting in immune 


\begin{tabular}{|c|c|c|c|}
\hline Parameter & Result & Normal range & Status \\
\hline White blood cell & $9.4 \times 10 * 9 / L$ & $4.0-10.0$ & Normal \\
\hline Lymphocyte \% & $19.7 \%$ & $20.0-40.0$ & Low \\
\hline MID\% & $7.3 \%$ & $1.0-15.0$ & Normal \\
\hline Neutrophil \% & $73.0 \%$ & $50.0-70.0$ & High \\
\hline Lymphocyte number & $1.9 \times 10 * 9 / L$ & $0.6-4.1$ & Normal \\
\hline MID number & $0.7 \times 10 * 9 / L$ & $0.1-1.8$ & Normal \\
\hline Neutrophil number & $6.8 \times 10 * 9 / L$ & $2.0-7.8$ & Normal \\
\hline Red blood cell & $5.42 \times 10 * 12 / L$ & $3.50-5.50$ & Normal \\
\hline Hemoglobin & $13.2 \mathrm{~g} / \mathrm{dL}$ & $11.0-16.0$ & Normal \\
\hline Hematocrit & $45.3 \%$ & $36.0-48.0$ & Normal \\
\hline Mean corpuscular volume & $83.6 \mathrm{fL}$ & $80.0-99.0$ & Normal \\
\hline Mean corpuscular hemoglobin & $29.3 \mathrm{pg}$ & $26.0-32.0$ & Low \\
\hline Mean corpuscular hemoglobin concentration & $24.3 \mathrm{~g} / \mathrm{dL}$ & $32.0-36.0$ & Low \\
\hline Red blood cell distribution width-SD & $48.3 \mathrm{fL}$ & $37.0-54.0$ & Normal \\
\hline Red blood cell distribution width-CV & $12.6 \%$ & $11.5-14.5$ & Normal \\
\hline Platelet & $294 \times 10 * 9 / L$ & $100-450$ & Normal \\
\hline Mean platelet volume & $11.1 \mathrm{fL}$ & 7.4-10.4 & High \\
\hline Platelet distribution width & $16.9 \%$ & $10.0-17.0$ & Normal \\
\hline Procalcitonin & $0.32 \%$ & $0.10-0.28$ & High \\
\hline Platelet large cell ratio & $39.3 \%$ & $13.0-43.0$ & Normal \\
\hline
\end{tabular}

suppression. ${ }^{26}$ An increase in neutrophils (as seen in our patient) can happen during a severe infection or exposure to stress, seen in COVID-19 infection. ${ }^{2}$

During our patient's second infection, a CT scan was ordered to confirm the second infection. The scan results showed consolidation and opacities in different sites of both lungs, indicating that the patient has a second COVID-19 infection, although he was infected before.

In conclusion, all the above tests strongly indicate that the patient had a recurrent infection with SARS-CoV-2 virus. However, the symptoms and severity of COVID-19 were less during the second infection than the first one.

\section{Consent}

Written informed consent was obtained from the patient for the publication of the report and any associated images.

\section{Data availability}

All data underlying the results are available as part of the article and no additional source data are required.

\section{Acknowledgements}

The authors thank all the medical staff members involved in treating this patient.

1. Zhu N, Zhang D, Wang W, et al.: A novel coronavirus from patients with pneumonia in China, 2019. N EnglJ Med. 2020.

PubMed Abstract | Publisher Full Text | Free Full Text
2. Chen Y, Liu Q, Guo D: Emerging coronaviruses: genome structure, replication, and pathogenesis. J Med Virol. 2020; 92(4): 418-423.

PubMed Abstract | Publisher Full Text | Free Full Text 
3. Gandhi RT, Lynch JB, Del Rio C: Mild or moderate Covid-19. N EnglJ Med. 2020; 383(18): 1757-1766.

PubMed Abstract | Publisher Full Text

4. Dos Santos LA, de Góis Filho PG, Silva AMF, et al.: Recurrent COVID-19 including evidence of reinfection and enhanced severity in thirty Brazilian healthcare workers. J Infect. 2021 82(3): 399-406.

PubMed Abstract | Publisher Full Text | Free Full Text

5. Azam M, Sulistiana R, Ratnawati M, et al.: Recurrent SARS-CoV-2 RNA positivity after COVID-19: a systematic review and metaanalysis. Sci Rep. 2020; 10(1): 1-12.

PubMed Abstract | Publisher Full Text | Free Full Text

6. Bongiovanni M, Vignati M, Giuliani G, et al.: The dilemma of COVID-19 recurrence after clinical recovery. J Infect. 2020. PubMed Abstract | Publisher Full Text | Free Full Text

7. Zhang R, Deng W, He J, et al.: Case Report: Recurrence of Positive SARS-CoV-2 Results in Patients Recovered From COVID-19. Front Med. 2020; 7: 882

PubMed Abstract | Publisher Full Text | Free Full Text

8. Harrington D, Kele B, Pereira S, et al.: Confirmed Reinfection with SARS-CoV-2 Variant VOC-202012/01. Clin Infect Dis. 2021.

PubMed Abstract | Publisher Full Text | Free Full Text

9. Sekine T, Perez-Potti A, Rivera-Ballesteros O, et al.: Robust T cell immunity in convalescent individuals with asymptomatic or mild COVID-19. Cell. 2020; 183(1): 158-168. PubMed Abstract | Publisher Full Text | Free Full Text

10. Leonard-Lorant I, Delabranche X, Severac F, et al. Acute pulmonary embolism in COVID-19 patients on CT angiography and relationship to D-dimer levels. Radiology. 2020.

PubMed Abstract | Publisher Full Text | Free Full Text

11. Ling W: C-reactive protein levels in the early stage of COVID-19. Med Mal Infect. 2020.

PubMed Abstract | Publisher Full Text | Free Full Text

12. Kappert $K$, Jahić $A$, Tauber R: Assessment of serum ferritin as a biomarker in COVID-19: bystander or participant? Insights by comparison with other infectious and non-infectious diseases. Biomarkers. 2020 Jul 23; 0(ja): 1-36. PubMed Abstract | Publisher Full Text

13. Henry BM, de Oliveira MHS, Benoit S, et al.: Hematologic, biochemical and immune biomarker abnormalities associated with severe illness and mortality in coronavirus disease 2019 (COVID-19): a meta-analysis. Clin Chem Lab Med CCLM. 2020 Jun 25; 58(7): 1021-1028. PubMed Abstract | Publisher Full Text

14. Kirkcaldy RD, King BA, Brooks JT: COVID-19 and Postinfection Immunity: Limited Evidence, Many Remaining Questions. Jama. 2020; 323(22): 2245-2246.

PubMed Abstract | Publisher Full Text
15. Roy S: COVID-19 Reinfection: Myth or Truth? SN Compr Clin Med. 2020: 1-4.

PubMed Abstract | Publisher Full Text | Free Full Text

16. Chandrashekar A, Liu J, Martinot AJ, et al.: SARS-CoV-2 infection protects against rechallenge in rhesus macaques. Science. 2020. PubMed Abstract | Publisher Full Text | Free Full Text

17. Long Q-X, Liu B-Z, Deng H-J, et al.: Antibody responses to SARSCoV-2 in patients with COVID-19. Nat Med. 2020: 1-4 PubMed Abstract | Publisher Full Text

18. Ota M: Will we see protection or reinfection in COVID-19? Nature Publishing Group. 2020. PubMed Abstract | Publisher Full Text | Free Full Text

19. Watson J, Whiting PF, Brush JE: Interpreting a covid-19 test result. Bmj. 2020; 369. PubMed Abstract | Publisher Full Text

20. Bentivegna $E$, Sentimentale A, Luciani M, et al.: New IgM seroconversion and positive RT-PCR test after exposure to the virus in recovered COVID-19 patient. J Med Virol. 2020. PubMed Abstract | Publisher Full Text | Free Full Text

21. Connors JM, Levy JH: COVID-19 and its implications for thrombosis and anticoagulation. Blood. 2020 Jun 4; 135(23): 2033-2040

PubMed Abstract | Publisher Full Text | Free Full Text

22. Zhai Z, Li C, Chen Y, et al.: Prevention and Treatment of Venous Thromboembolism Associated with Coronavirus Disease 2019 Infection: A Consensus Statement before Guidelines. Thromb Haemost. 2020 Jun; 120(6): 937-948. PubMed Abstract | Publisher Full Text | Free Full Text

23. Dhesi Z, Enne VI, O'Grady J, et al.: Rapid and Point-of-Care Testing in Respiratory Tract Infections: An Antibiotic Guardian? ACS Pharmacol Trans/ Sci. 2020 Jun 12: 3(3): 401-417. PubMed Abstract | Publisher Full Text | Free Full Text

24. Haitao T, Vermunt JV, Abeykoon J, et al.: COVID-19 and Sex Differences: Mechanisms and Biomarkers. Mayo Clin Proc. 2020 Oct 1; 95(10): 2189-2203 PubMed Abstract | Publisher Full Text | Free Full Text

25. Alejandre C, Guitart C, Balaguer M, et al.: Use of procalcitonin and $C$-reactive protein in the diagnosis of bacterial infection in infants with severe bronchiolitis. Eur J Pediatr. 2020 Sep 14 [cited 2020 Oct 15].

PubMed Abstract | Publisher Full Text

26. Tan L, Wang $Q$, Zhang $D$, et al.: Lymphopenia predicts disease severity of COVID-19: a descriptive and predictive study. Signal Transduct Target Ther. 2020 Mar 27; 5(1): 1-3. PubMed Abstract | Publisher Full Text | Free Full Text

27. Wang J, Li Q, Yin Y, et al.: Excessive Neutrophils and Neutrophil Extracellular Traps in COVID-19. Front Immunol. 2020 [cited 2020 Oct 12]; 11.

PubMed Abstract | Publisher Full Text | Free Full Text | Reference Source 


\section{Open Peer Review}

\section{Current Peer Review Status:}

\section{Version 1}

Reviewer Report 17 August 2021

\section{https://doi.org/10.5256/f1000research.57065.r89733}

(C) 2021 Allawe A. This is an open access peer review report distributed under the terms of the Creative Commons Attribution License, which permits unrestricted use, distribution, and reproduction in any medium, provided the original work is properly cited.

Aida B. Allawe

College of Veterinary Medicine, The University of Baghdad, Baghdad, Iraq

This research is greatly needed in order to get a better understanding of this new pandemic. The details of the clinical signs and case history are clearly explained. In addition, the clinical diagnostic steps and treatment are both properly illustrated.

However, more research is needed to better understand the disease process, diagnosis, and treatment since it is a new pandemic and scientists have not fully understood it. For instance, the effect of age, sex, other illnesses, and the environment on the susceptibility of infection. Additionally, there is no evidence that refers that the virus persists after infection.

Is the background of the case's history and progression described in sufficient detail? Yes

Are enough details provided of any physical examination and diagnostic tests, treatment given and outcomes?

Yes

Is sufficient discussion included of the importance of the findings and their relevance to future understanding of disease processes, diagnosis or treatment? Partly

Is the case presented with sufficient detail to be useful for other practitioners? Yes

Competing Interests: No competing interests were disclosed.

I confirm that I have read this submission and believe that I have an appropriate level of expertise to confirm that it is of an acceptable scientific standard. 
The benefits of publishing with F1000Research:

- Your article is published within days, with no editorial bias

- You can publish traditional articles, null/negative results, case reports, data notes and more

- The peer review process is transparent and collaborative

- Your article is indexed in PubMed after passing peer review

- Dedicated customer support at every stage

For pre-submission enquiries, contact research@f1000.com 